\title{
Pikkuvasikoiden kasvu ja terveys iglukasvatuksessa
}

\author{
Leena Tuomisto $^{1)}$, Auvo Sairanen ${ }^{1)}$, Arto Huuskonen ${ }^{1)}$, Kaisa Hartikainen ${ }^{2)}$, Anni Tarkiainen ${ }^{3)}$ ja Risto \\ Kauppinen $^{2)}$ \\ ${ }^{1)}$ Maa- ja elintarviketalouden tutkimuskeskus, Kotieläintuotannon tutkimus, Halolantie 31 A, 71750 \\ Maaninka,etunimi.sukunimi@mtt.fi \\ ${ }^{2)}$ Savonia-ammattikorkeakoulu, PL 72, 74101 Iisalmi,etunimi.sukunimi@savonia-amk.fi \\ ${ }^{3)}$ Kuopion yliopisto, Biotieteiden laitos, PL 1627, 70211 Kuopio,apekkane@hytti.uku.fi
}

\section{Tiivistelmä}

Kokeemme tarkoituksena oli tutkia vasikoiden kasvua ja terveyttä iglukasvatuksessa ja perinteisessä sisäkasvatuksessa. Koe tehtiin MTT Maaningan toimipaikassa maalis-kesäkuussa 2009. Kokeen 19 sonnivasikkaa ja 13 lehmävasikkaa syntyivät helmi-huhtikuussa. Koekäsittelyt olivat 1) kasvatus ulkona iglussa (2 vasikkaa/iglu), 2) kasvatus sisäkarsinassa lämpimässä navetassa (2 vasikkaa/karsina). Vasikkaiglut olivat 1,2 × 2,0 m ja niiden edessä oli etukarsina 1,2 x 1,5 m. Sisäkarsinat $(1,2 \times 3,0 \mathrm{~m})$ oli muodostettu yhdistämällä kolme yksittäiskarsinaa. Igluissa ja karsinoissa käytettiin kuivikkeena olkea. Vasikat siirrettiin koeympäristöihin pareittain sitä mukaa kuin ne syntyivät. Kokeen alkaessa vasikat olivat $4,3 \pm 1,7$ vrk ikäisiä ja kokeen päättyessä $73,5 \pm 1,6$ vrk ikäisiä. Vasikoille tarjottiin lämmintä hapanjuomaa tuttisangoista $8 \mathrm{l} / \mathrm{vrk}$. Juomalta vieroitus alkoi vasikoiden seitsemän viikon iässä. Vasikat saivat vapaasti kuivaa heinää sekä teollista täysrehua korkeintaan $3 \mathrm{~kg} / \mathrm{vrk} / \mathrm{eläin.} \mathrm{Juo-}$ mavesi tarjottiin lämpimänä juottojen yhteydessä. Vasikoiden rehun syönti mitattiin päivittäin ja kasvua seurattiin punnituksin kahden viikon välein. Vasikoiden terveydentilaa seurattiin päivittäin ja 42,2 $\pm 7,0$ vuorokauden iässä vasikoilta otettiin ulostenäytteet ja syväsivelynäytteet hengitysteistä taudinaiheuttajien kartoittamiseksi. Dataloggerit mittasivat iglujen ja karsinoiden lämpötilaa. Muuttujien tilastollinen testaus tehtiin lineaarisella sekamallilla. Igluissa mitattu alin lämpötila kokeen aikana oli maaliskuussa $-16,5^{\circ} \mathrm{C}$ ja ylin lämpötila kesäkuussa $+35,7^{\circ} \mathrm{C}$. Sisäkarsinoissa lämpötila pysyi tasaisempana $\left(\min +10,1{ }^{\circ} \mathrm{C}\right.$ ja $\left.\max +25,1^{\circ} \mathrm{C}\right)$. Sisävasikat söivät kokeen aikana keskimäärin $37 \%$ enemmän väkirehua ja $26 \%$ enemmän heinää kuin igluvasikat $(\mathrm{P}<0,05)$. Sisävasikoiden kokonaissyönti $(\mathrm{kg}$ ka/eläin/vrk) oli kokeen aikana keskimäärin $17 \%$ ja energian saanti (MJ/eläin/vrk) $13 \%$ suurempi kuin igluvasikoilla $(\mathrm{P}<0,01)$. Sisävasikat kasvoivat keskimäärin $16 \%$ paremmin kuin igluvasikat. Lehmävasikoiden kasvussa ei ollut eroja käsittelyjen välillä (keskimäärin $817 \mathrm{~g} / \mathrm{vrk}$ ), mutta sonnivasikat kasvoivat paremmin sisäkarsinoissa kuin igluissa (983 vs. $753 \mathrm{~g} / \mathrm{vrk}, \mathrm{P}<0,001$ ). Vasikoilla ei ilmennyt hengitystietulehduksia, mutta ripulia havaittiin kymmenellä igluvasikalla 2,9 $\pm 1,3$ päivän ajan ja kolmella sisävasikalla 2,3 $\pm 1,2$ päivän ajan. Vasikoiden rehun syönti ja energian saanti olivat pienemmät igluvasikoilla kuin sisävasikoilla. Päiväkasvu kärsi etenkin igluissa kasvatetuilla sonnivasikoilla. Rehun ajoittainen kosteus ja kylmyys mahdollisesti heikensivät igluvasikoille tarjolla olleen rehun maittavuutta. Ruokinta-astioiden sijainti iglujen ulkopuolella etukarsinassa ei siten välttämättä ollut optimaalinen. Lämpötila nousi kesällä ajoittain hyvin korkeaksi iglujen sisällä, minkä vuoksi iglut on suositeltavaa sijoittaa suojaan suoralta auringonpaisteelta. Iglukasvatus näytti lisäävän ripulia sairastavien eläinten määrää.

Asiasanat: vasikat, kasvatusympäristöt, kylmäkasvatus, iglut, kasvu, terveys 


\section{Johdanto}

Perinteiset vasikoiden kasvatustilat ja hoitomenetelmät ovat usein monin tavoin puutteellisia eläimen terveyden ja hyvinvoinnin kannalta. Tilojen ahtaus, vetoisuus, kosteus, huono ilmastointi ja kuivituksen puute ovat yleisiä ongelmia. Huonot olosuhteet altistavat vasikoita erityisesti hengitysteiden sairauksille ja suolistoperäisille sairauksille (Andrews 1992, van der Fels-Klerx ym. 2000). Pikkuvasikoiden kasvattaminen ulkona ns. igluissa on yleistä Pohjois-Amerikassa ja Keski-Euroopassa. Kasvatusmallissa tavoitellaan terveempiä vasikoita siirtämällä vasikat pian syntymän jälkeen ulos igluihin raittiiseen ilmaan pienempään tautipaineeseen.

Suurelle naudalle kylmyys ei ole ongelma, jos eläimet ovat laumassa, tarjolla on hyvä tuulensuoja ja kuiva makuualusta sekä riittävästi rehua ja puhdasta juomavettä (Huuskonen ym. 2009, Tuomisto ym. 2009). Pikkuvasikoiden hyvinvointi on kuitenkin suurta nautaa haavoittuvaisempi. Nuori vasikka ei siedä kylmää yhtä hyvin kuin aikuinen nauta, koska nuoren vasikan lämmöntuottokyky on pienempi ja kudosten ja karvapeitteen tarjoama eristys heikompi kuin aikuisella eläimellä (GonzalezJimenez \& Blaxter 1962, Webster 1971). Pienten vasikoiden kasvattaminen kylmässä herättää usein huolta eläinten terveydestä ja hyvinvoinnista. Kokeemme tarkoituksena oli selvittää vasikoiden kasvua ja terveyttä iglukasvatuksessa ja perinteisessä sisäkasvatuksessa lämpimässä navetassa. Kokeen yhteydessä toteutettiin myös vasikoiden käyttäytymistutkimus, jonka tulokset raportoidaan myöhemmin.

Tässä raportoitu tutkimus on osa Maa- ja elintarviketalouden tutkimuskeskuksen (MTT) hallinnoimaa InnoNauta Kehitys -hanketta. InnoNauta -hankkeet ovat saaneet rahoitusta Euroopan maaseudun kehittämisen Maatalousrahastosta. Tuki on myönnetty hankealueiden TE-keskusten toimesta. Hankkeiden yhteistyökumppaneina toimivat TTS tutkimus, AtriaNauta ja Valio Oy. Myös Savoniaammattikorkeakoulun Laadukas tuote - laadukas tuotantoketju -hanke on osallistunut tutkimuksen rahoittamiseen.

\section{Aineisto ja menetelmät}

Tutkimus tehtiin MTT Maaningan toimipaikassa keväällä 2009. Koe alkoi maaliskuussa ja päättyi kesäkuussa. Kokeessa käytetyt 19 sonnivasikkaa ja 13 lehmävasikkaa syntyivät helmi-huhtikuussa MTT Maaningan tutkimusnavetassa. Koekäsittelyt olivat 1) kasvatus ulkona vasikkaiglussa (2 vasikkaa/iglu), 2) kasvatus sisäkarsinassa lämpimässä navetassa (2 vasikkaa/karsina). Vasikkaiglut olivat kooltaan 120 × $200 \mathrm{~cm}$ ja niiden edessä oli etukarsina $120 \times 150 \mathrm{~cm}$ (tilaa yhteensä 2,1 m²/eläin). Vasikkaiglut oli sijoitettu suojaisalle sisäpihalle. Lämpimän navetan sisäkarsinat $(120 \times 305 \mathrm{~cm})$ oli muodostettu yhdistämällä kolme yksittäiskarsinaa (tilaa $1,8 \mathrm{~m}^{2} / \mathrm{eläin).} \mathrm{Igluissa} \mathrm{ja} \mathrm{karsinoissa} \mathrm{käytettiin}$ kuivikkeena olkea. Sisäkarsinoissa lisälämmönlähteenä käytettiin karsinan yläpuolelle kiinnitettäviä lämpölamppuja (1 lamppu/karsina) vasikoiden neljän viikon ikään asti. Dataloggerit rekisteröivät iglujen ja sisäkarsinoiden lämpötilaa jatkuvasti.

Kaikki vastasyntyneet vasikat siirrettiin syntymän jälkeen yksittäiskarsinoihin lämpölampun alle. Lämpölamppu poistettiin igluun siirrettäviltä vasikoilta ensimmäisen vuorokauden jälkeen. Vasikat siirrettiin koeympäristöihin pareittain sitä mukaa kuin ne syntyivät vasikkaparin nuoremman vasikan ollessa noin kolmen vuorokauden ikäinen. Igluvasikoilla käytettiin igluihin siirron jälkeisinä kahtena ensimmäisenä päivänä lämpöliivejä lieventämään siirron aiheuttamaa termistä stressiä. Kokeen alkaessa vasikat olivat 4,3 $\pm 1,7$ (keskiarvo \pm keskihajonta) vuorokauden ikäisiä ja kokeen päättyessä 73,5 \pm 1,6 vuorokauden ikäisiä. Igluryhmässä oli 7 lehmävasikkaa ja 9 sonnivasikkaa. Sisäkarsinaryhmässä oli 6 lehmävasikkaa ja 10 sonnivasikkaa.

Vasikoille tarjottiin maidosta AIV-hapolla hapatettua lämmintä $\left(+35^{\circ} \mathrm{C}\right)$ hapanjuomaa tuttisangoista aluksi 7,5 1/vrk ja kahden viikon iästä alkaen 8 1/vrk. Kahden viikon pituinen juotolta vieroitus alkoi vasikoiden seitsemän viikon iässä. Vasikat kytkettiin kiinni juoton ajaksi, jotta toisen eläimen juoman varastaminen estyi. Tuttisangot kerättiin pois 15 minuutin kuluttua juotosta. Vasikat saivat koko kokeen ajan vapaasti kuivaa heinää sekä teollista täysrehua (Raision MullinHerkku 1) korkeintaan $3 \mathrm{~kg} / \mathrm{vrk} / \mathrm{eläin}$. Juomavesi tarjottiin kaikille vasikoille lämpimänä $\left(+35-40{ }^{\circ} \mathrm{C}\right)$ juottojen yhteydessä. Sisäkarsinoissa juomavesi, heinä ja väkirehu tarjottiin kukin omasta ämpäristään. Igluissa juomavesi ja heinä tarjottiin omista ämpäreistään ja väkirehu katetusta väkirehuastiasta. Igluissa ruokintaastiat sijaitsivat etukarsinassa. Jokaiseen igluun ja karsinaan oli kiinnitetty huvitutti. Karsinoita ja igluja kuivitettiin oljella useita kertoja viikossa.

Kokeen aikana vasikoiden rehunkulutus mitattiin päivittäin ja kasvua seurattiin punnituksin kahden viikon välein. Kokeessa käytettyjen rehujen kemiallinen koostumus (kuiva-aine, raakavalkuai- 
nen, raakarasva, NDF-kuitu) määritettiin Ahvenjärven ym. (2000) kuvailemalla tavalla. Rehujen energia- ja valkuaisarvot laskettiin rehutaulukoiden (MTT 2006) mukaan. Vasikoiden terveydentilaa seurattiin päivittäin ja lisäksi kerran kokeen aikana vasikoista otettiin ulostenäytteet ja syväsivelynäytteet hengitysteistä mahdollisten taudinaiheuttajamikrobien kartoittamiseksi. Näytteenottohetkellä vasikat olivat 42,2 \pm 7,0 vuorokauden ikäisiä. Uloste- ja syväsivelynäytteet tutkittiin EVIRA:n Kuopion toimipisteessä.

Tilastollisia analyyseja varten vasikat jaettiin kahteen blokkiin. Blokin 1 vasikat (talvivasikat) aloittivat kokeessa 2.3.-22.3.2009 välisenä aikana ja lopettivat kokeessa 10.5.-31.5.2009 välisenä aikana. Blokin 2 vasikat (kevätvasikat) aloittivat kokeessa 30.3.-29.4.2009 välisenä aikana ja lopettivat kokeessa 8.6.-1.7.2009 välisenä aikana. Vasikoiden sukupuolet jakautuivat melko tasaisesti blokkeihin. Talvivasikoissa igluissa oli viisi sonnivasikkaa ja kolme lehmävasikkaa ja sisäkarsinoissa kuusi sonnivasikkaa ja kaksi lehmävasikkaa. Kevätvasikoissa igluissa ja sisäkarsinoissa oli molemmissa neljä lehmävasikkaa ja neljä sonnivasikkaa. Muuttujien tilastollinen testaus tehtiin lineaarisella sekamallilla SPSS for Windows 14.0 -ohjelmalla. Mallin yleinen muoto oli: $Y_{i j k l}=\mu+\beta_{i}+\gamma_{j}+\theta_{k}+\beta \gamma_{i j}+$ $\beta \theta_{i k}+\gamma \theta_{j k}+\beta \gamma_{i j k}+\varphi_{l}+\varepsilon_{i j k l}$, jossa $\mu=$ yleiskeskiarvo, $\beta_{i}=$ käsittelyn $i$ kiinteä vaikutus, $\gamma_{j}=$ sukupuolen $j$ kiinteä vaikutus, $\theta_{k}=$ blokin $k$ kiinteä vaikutus, $\beta \gamma_{i j}=$ käsittelyn $i$ ja sukupuolen $j$ yhdysvaikutus, $\beta \theta_{i k}=$ käsittelyn $i$ ja blokin $k$ yhdysvaikutus, $\gamma \theta_{j k}=$ sukupuolen $j$ ja blokin $k$ yhdysvaikutus, $\beta \gamma \theta_{i j k}$ käsittelyn $i$, sukupuolen $j$ ja blokin $k$ yhdysvaikutus, $\varphi_{l}=$ iglun tai karsinan $l$ satunnaisvaikutus ja $\varepsilon_{i j k l}=$ virhetermi. Väkirehun syönnin, heinän syönnin, kokonaissyönnin, energian saannin sekä rehun muuntosuhteen analyyseissa vasikan sukupuolen vaikutus poistettiin tilastollisesta mallista, koska vasikoiden syöntiä ei pystytty määrittämään yksilökohtaisesti.

\section{Tulokset ja tulosten tarkastelu}

Igluissa, sisäkarsinoissa ja ulkoilmassa mitatut minimi-, maksimi ja keskilämpötilat on esitetty taulukossa 1. Iglujen sisällä mitattu keskilämpötila oli maaliskuussa $-1,7^{\circ} \mathrm{C}$, huhtikuussa $+3,8{ }^{\circ} \mathrm{C}$, toukokuussa $+13,1{ }^{\circ} \mathrm{C}$ ja kesäkuussa $+15,3{ }^{\circ} \mathrm{C}$. Iglujen keskilämpötila oli noin $2{ }^{\circ} \mathrm{C}$ korkeampi kuin ulkoilman vastaava lämpötila. Alin igluissa mitattu lämpötila oli $-16,5^{\circ} \mathrm{C}$ ja korkein $+35,7^{\circ} \mathrm{C}$. Kokeen aikana $+30{ }^{\circ} \mathrm{C}$ ylittäviä lämpötiloja mitattiin igluissa yhtenä päivänä toukokuussa ja kolmena päivänä kesäkuussa. Koska iglujen sisälämpötila nousi ajoittain hyvin korkeaksi, iglut olisi suotavaa sijoittaa esimerkiksi katoksen alle varjoon suojaan suoralta auringonpaisteelta vasikoiden lämpöstressin vähentämiseksi (Coleman ym. 1996, Spain \& Spiers 1996). Sisäkarsinoissa lämpötilojen vaihtelu oli pienempää kuin igluissa. Keskilämpötila oli maaliskuussa ja huhtikuussa $+14,5^{\circ} \mathrm{C}$, toukokuussa $+17,9^{\circ} \mathrm{C}$ ja kesäkuussa $+18,4{ }^{\circ} \mathrm{C}$.

Taulukko 1. Igluissa, sisäkarsinoissa ja ulkoilmassa mitatut minimi-, maksimi ja keskilämpötilat $\left({ }^{\circ} \mathrm{C}\right)$ maalis-, huhti-, touko- ja kesäkuussa.

\begin{tabular}{llllllllll}
\hline & \multicolumn{1}{c}{ Iglut } & \multicolumn{4}{c}{ Sisäkarsinat } & \multicolumn{4}{c}{ Ulkoilma ${ }^{1}$} \\
& min. & max. & ka. & $\min$. & $\max$. & ka. & min. & max. & ka. \\
\hline Maaliskuu & $-16,5$ & $+9,0$ & $-1,7$ & $+10,1$ & $+17,7$ & $+14,5$ & $-19,3$ & $+5,8$ & $-3,5$ \\
Huhtikuu & $-8,1$ & $+24,4$ & $+3,8$ & $+11,7$ & $+18,6$ & $+14,5$ & $-10,9$ & $+15,5$ & $+1,8$ \\
Toukokuu & $+0,6$ & $+34,8$ & $+13,1$ & $+14,2$ & $+24,1$ & $+17,9$ & $-1,1$ & $+26,9$ & $+10,6$ \\
Kesäkuu & $+2,6$ & $+35,7$ & $+15,3$ & $+13,4$ & $+25,1$ & $+18,4$ & $+1,6$ & $+28,2$ & $+13,0$ \\
\hline
\end{tabular}

${ }^{1}$ Lämpötilatiedot on saatu MTT Maaningalla sijaitsevalta Ilmatieteen laitoksen havaintoasemalta.

Kokeessa käytettyjen rehujen rehuarvot on esitetty taulukossa 2. Vasikoiden hapanjuoman juonnissa ei ollut eroja iglu- ja sisävasikoiden välillä kokeen aikana (Taulukko 3). Sisävasikat kuitenkin söivät kokeen aikana enemmän väkirehua (619 vs. 451 g KA/vrk, $\mathrm{P}<0,01)$ ja heinää ( 267 vs. $212 \mathrm{~g} \mathrm{KA}$ /vrk, $\mathrm{P}<0,05)$ kuin igluvasikat. Tämän seurauksena myös kokonaissyönti (1,59 vs. 1,36 kg ka/eläin/vrk, $\mathrm{P}<0,01)$ ja energian saanti $(25,5$ vs. $22,5 \mathrm{MJ} /$ eläin/vrk, $\mathrm{P}<0,01)$ olivat suuremmat sisä- kuin igluvasikoilla. Rehun kuiva-aineen syönnin kehittyminen kokeen aikana on esitetty kuvassa 1 . Käyrien perusteella igluvasikoiden rehun syönti ei kasvanut samaa tahtia kuin sisävasikoiden rehun syönti ja koeryhmien välinen ero rehun syönnissä oli suurimmillaan viimeisten koeviikkojen aikana. Samansuuntainen kehitys on nähtävissä vasikoiden energian saannissa kokeen aikana (Kuva 2).

Lehmävasikoista talvella kokeessa aloittaneet eläimet joivat hapanjuomaa vähemmän kuin keväällä kokeessa aloittaneet eläimet (678 vs. $716 \mathrm{~g} \mathrm{KA}$ /vrk, P<0,01) (Taulukko 3). Lisäksi talvivasikat söivät 
vähemmän väkirehua kuin kevätvasikat (467 vs. $604 \mathrm{~g} \mathrm{KA}$ /vrk, $\mathrm{P}<0,01$ ), minkä seurauksena talvivasikoiden kokonaissyönti (1,40 vs. 1,55 kg KA/vrk, $\mathrm{P}<0,01)$ ja energian saanti $(22,9$ vs. 25,1 MJ/vrk, $\mathrm{P}<0,01)$ olivat pienemmät kuin kevätvasikoilla. Tutkimustuloksemme on igluvasikoiden osalta ristiriitainen aikaisempien tulosten kanssa, joissa kylmissä olosuhteissa kasvatus on lisännyt vasikoiden rehun syöntiä (McKnight 1978, Kauppinen ym. 2002) tai ei ole vaikuttanut siihen (Jorgenson ym. 1970, Hepola ym. 2006). Igluvasikoiden heikompi syönti talvella saattoi johtua kylmästä ja ajoittain kosteasta rehusta, koska ruokinta-astiat sijaitsivat iglujen etukarsinoissa osittain tai kokonaan alttiina sateelle ja kosteudelle. Rehun ajoittainen kosteus ja kylmyys mahdollisesti heikensivät igluvasikoille tarjolla olleen rehun maittavuutta. On kuitenkin epäselvää, miksi rehun syönti oli vähentynyt myös sisällä pidetyillä talvivasikoilla. Kokeessamme rehun muuntosuhde ei eronnut koekäsittelyjen välillä. Rehujen haaskaantuminen ruokinta-astioiden ulkopuolelle ja rehun ajoittainen kastuminen vaikeutti syönnin mittaamista ja lisää koevirheen mahdollisuutta.

Taulukko 2. Kokeessa käytettyjen rehujen kemiallinen koostumus ja rehuarvot.

\begin{tabular}{lccc}
\hline & Maito & Heinä & Täysrehu \\
\hline Kuiva-aine, g/kg & 120 & 830 & 888 \\
Raakavalkuainen, g/kg ka & 333 & 97 & 205 \\
Raakarasva, g/kg ka & 400 & 20 & 52 \\
NDF-kuitu, g/kg ka & - & 653 & 249 \\
Energia-arvo, ry/kg ka & 1,76 & 0,77 & 1,05 \\
Energia-arvo, MJ ME/kg ka & 20,6 & 9,0 & 12,3 \\
OIV, g/kg ka & 223 & 77 & 115 \\
\hline
\end{tabular}

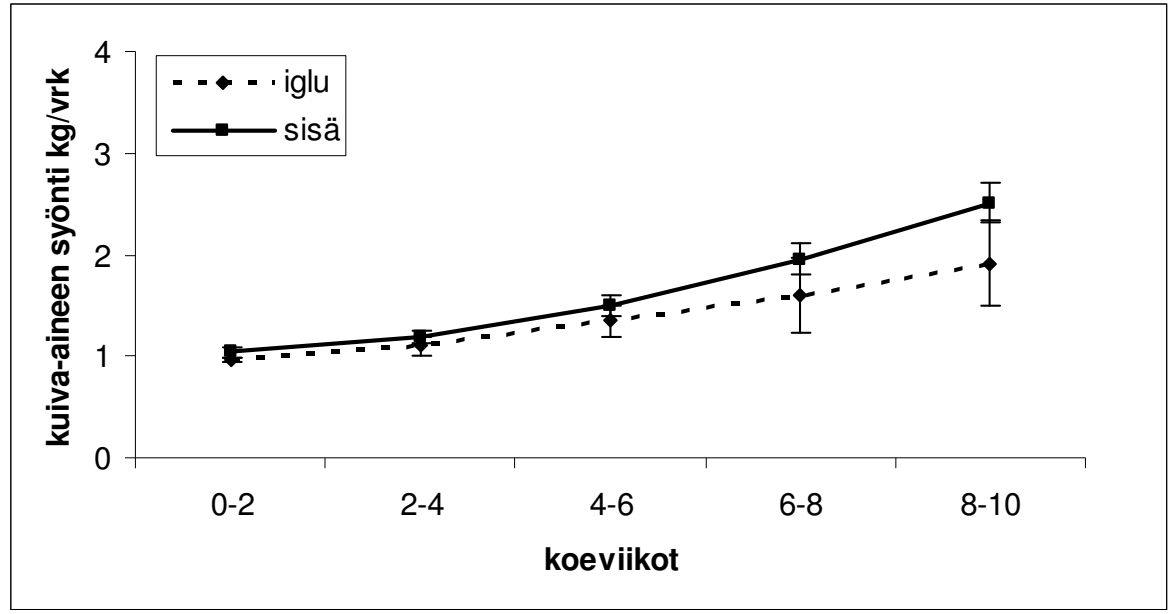

Kuva 1. Vasikoiden rehun kuiva-aineen syönti kokeen aikana.

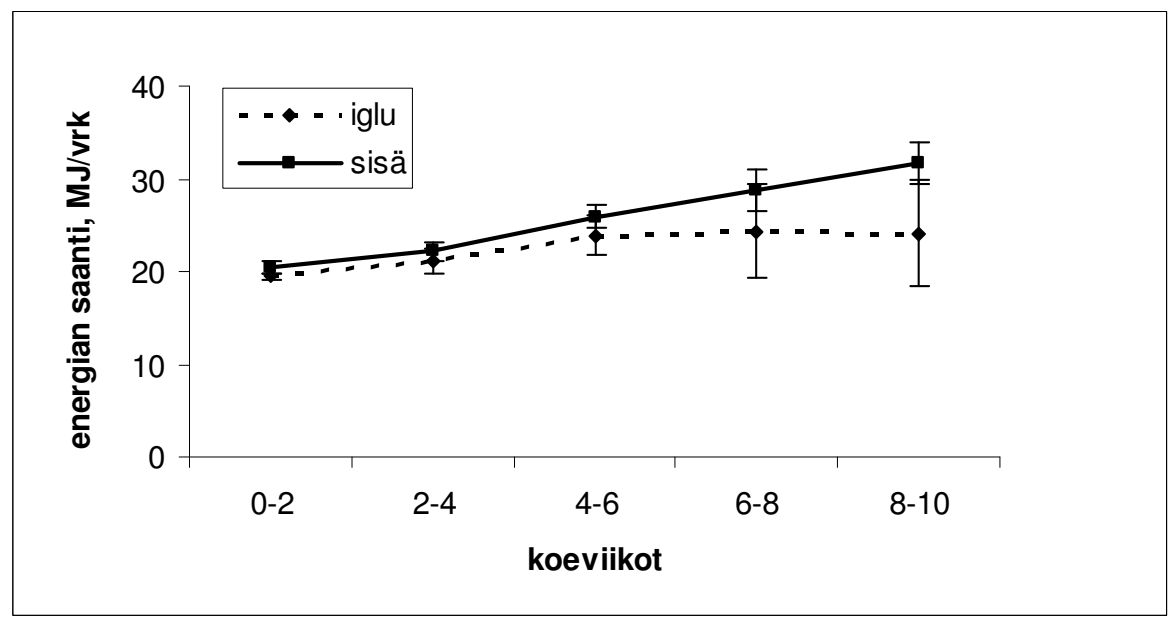

Kuva 2. Vasikoiden energian saanti kokeen aikana. 
SUOMEN MAATALOUSTIETEELLISEN SEURAN TIEDOTE NRO 26

Taulukko 3. Vasikoiden rehun syönti, ravintoaineiden saanti, rehun muuntosuhde sekä elopaino ja päiväkasvu päävaikutuksittain kokeen aikana.

\begin{tabular}{|c|c|c|c|c|c|c|c|c|c|c|c|c|c|c|c|c|}
\hline & \multicolumn{3}{|c|}{ Kasvatusympäristö (K) } & \multicolumn{3}{|c|}{ Sukupuoli (S) } & \multicolumn{3}{|c|}{ Blokki (B) } & \multicolumn{7}{|c|}{ Tilastollinen merkitsevyys $^{2)}$} \\
\hline & Iglut & Sisä & SEM $^{1)}$ & Lehmä & Sonni & SEM & Talvi & Kevät & SEM & $\mathrm{K}$ & $S$ & B & $\mathrm{KxS}$ & $\mathrm{KxB}$ & $\mathrm{SxB}$ & $\mathrm{KxSxB}$ \\
\hline hapanjuoma, g KA/vrk & 699 & 700 & 0,01 & 697 & 702 & 0,01 & 688 & 710 & 0,01 & & & $*$ & & & $* *$ & o \\
\hline väkirehu, g KA/vrk & 451 & 619 & 0,03 & - & - & - & 467 & 604 & 0,03 & $* *$ & - & $* *$ & - & & - & - \\
\hline heinä, g KA/vrk & 212 & 267 & 0,02 & - & - & - & 238 & 240 & 0,02 & $*$ & - & & - & & - & - \\
\hline syönti yhteensä, kg KA/vrk & 1,36 & 1,59 & 0,04 & - & - & - & 1,40 & 1,55 & 0,04 & $* *$ & - & $*$ & - & & - & - \\
\hline energian saanti, MJ/vrk & 22,5 & 25,5 & 0,51 & - & - & - & 22,9 & 25,1 & 0,51 & $* *$ & - & $*$ & - & & - & - \\
\hline $\begin{array}{l}\text { rehun muuntosuhde, } \\
\mathrm{MJ} / \mathrm{kasvu}-\mathrm{kg}\end{array}$ & 28,6 & 27,7 & 0,78 & - & - & - & 27,3 & 29,1 & 0,78 & & - & & - & & - & - \\
\hline elopaino kokeen alussa, kg & 49,3 & 49,5 & 1,65 & 46,7 & 52,1 & 1,8 & 48,7 & 50,1 & 1,7 & & $*$ & & & & & \\
\hline $\begin{array}{l}\text { elopaino kokeen lopussa, } \\
\mathrm{kg}\end{array}$ & 102,6 & 110,8 & 2,68 & 102,2 & 111,3 & 2,9 & 104,7 & 108,7 & 2,7 & $*$ & $*$ & & $* *$ & & & \\
\hline päiväkasvu, g/vrk & 780 & 904 & 0,03 & 817 & 868 & 0,03 & 813 & 872 & 0,03 & $* *$ & & & $*$ & & & \\
\hline
\end{tabular}

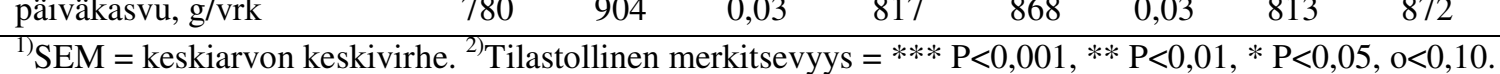


Sonnivasikat olivat kokeen alussa painavampia kuin lehmävasikat $(52,1$ vs. 46,7 kg, $\mathrm{P}<0,05)$, mutta vasikoiden alkupainoissa ei ollut eroa koekäsittelyjen välillä (Taulukko 3). Kokeen lopussa igluissa kasvatetut sonnivasikat olivat merkitsevästi pienempiä kuin sisällä kasvatetut sonnivasikat (101,9 vs. $120,7 \mathrm{~kg}, \mathrm{P}<0,001)$. Kokeen aikana sisävasikat kasvoivat keskimäärin $16 \%$ paremmin kuin igluvasikat. Tämä ero kuvaa varsin hyvin eroa eläinten rehun syönnissä ja energian saannissa keskimäärin koekäsittelyjen välillä. Kokeen aikana sisäkarsinoissa kasvatetut sonnivasikat saavuttivat parhaan kasvutuloksen, mikä voidaan havaita myös vasikoiden elopainon kehitystä kuvaavista käyristä (Kuva 3). Lehmävasikoiden kasvussa ei ollut eroja käsittelyjen välillä (iglu $808 \mathrm{~g} / \mathrm{vrk}$ vs. sisäkarsinat $826 \mathrm{~g} / \mathrm{vrk}$ ), mutta sonnivasikat kasvoivat paremmin sisäkarsinoissa kuin igluissa (983 vs. $753 \mathrm{~g} / \mathrm{vrk}, \mathrm{P}<0,001$ ). Kaiken kaikkiaan vasikat kasvoivat hyvin tai tyydyttävästi; niiden keskimääräinen kasvu oli samaa luokkaa kuin maitorotuisten sonnivasikoiden ensimmäisen kahdeksan viikon kasvu sisäkarsinoissa Huuskosen ym. (2005) tutkimuksessa.

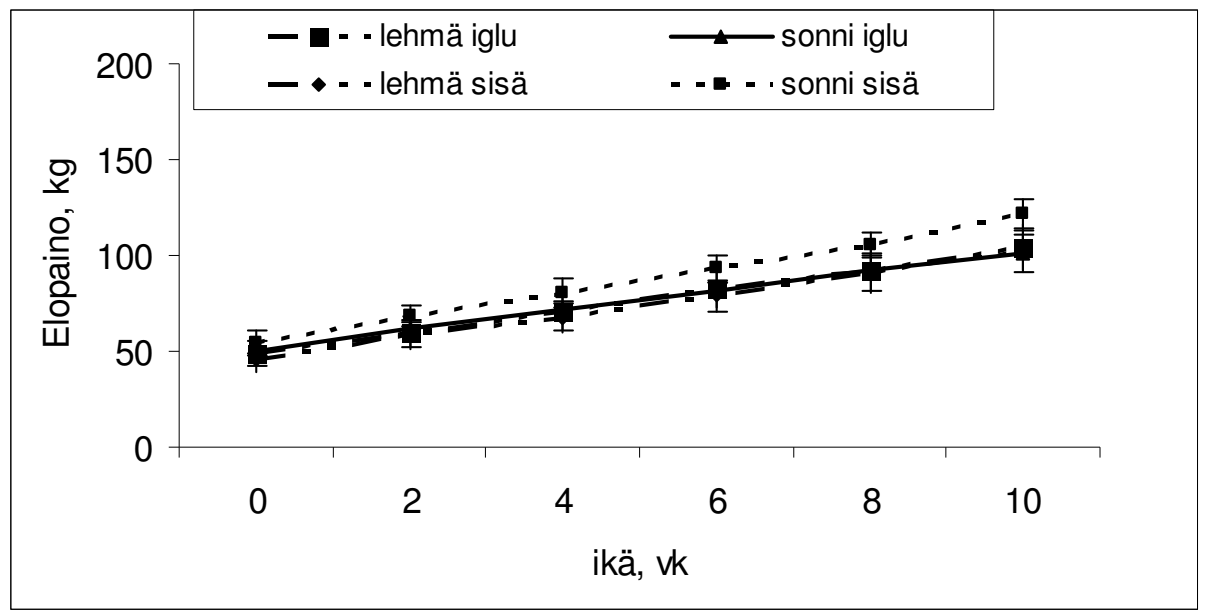

Kuva 3. vasikoiden elopainon kehitys kokeen aikana.

Kokeen aikana vasikoilla ei ilmennyt hengitystietulehduksia. Ripulia havaittiin igluissa kymmenellä vasikalla 2,9 $\pm 1,3$ päivän ajan ja sisäkarsinoissa kolmella vasikalla $2,3 \pm 1,2$ päivän ajan. Ulostenäytteissä havaittiin kokkideja (Eimeria $s p$.) viidellä igluvasikalla ja kahdella sisävasikalla sekä rotavirusta kahdella igluvasikalla ja neljällä sisävasikalla. Hengitysteistä otetusta syväsivelynäytteistä löydettiin mykoplasmoja kolmelta igluvasikalta ja yhdeltä sisävasikalla sekä koronavirusta kolmelta igluvasikalta.

\section{Johtopäätökset}

Vasikoiden rehun syönti ja energian saanti olivat pienemmät igluissa kuin sisäkarsinoissa kasvatetuilla vasikoilla. Vasikoiden rehun syönti ja energian saanti olivat pienemmät myös talvella kuin keväällä kokeessa aloittaneilla vasikoilla. Rehun ajoittainen kosteus ja kylmyys mahdollisesti heikensivät igluvasikoille tarjolla olleen rehun maittavuutta. Ruokinta-astioiden sijainti iglujen ulkopuolella etukarsinassa ei siten välttämättä ollut optimaalinen. Päiväkasvu kärsi etenkin igluissa kasvatetuilla sonnivasikoilla. Lämpötila nousi kesällä ajoittain hyvin korkeaksi iglujen sisällä, minkä vuoksi iglut on suositeltavaa sijoittaa varjoon suojaan suoralta auringonpaisteelta. Iglukasvatus ei vaikuttanut hengitystietulehdusten esiintymiseen verrattuna sisäkasvatukseen, mutta näytti lisäävän ripulia sairastavien eläinten määrää.

\section{Kirjallisuus}

Ahvenjärvi, S., Vanhatalo, A., Huhtanen, P. \& Varvikko, T. 2000. Determination of reticulo-rumen and stomach digestion in lactating cows by omasal canal and duodenal sampling. Br. J. Nutr. 83: 67-77.

Andrews, A. H. 1992. Calf respiratory disease. Teoksessa: Toim. Andrews, A. H., Blowey, R. W., Bloyd, H. \& Eddy, R. G. Bovine medicine, diseases and husbandry of cattle. s. 202-211.

Broucek, J., Kisac, P., Uhrincat, M., Hanus, A. \& Benc, F. 2008. Effect of high temperature on growth performance of calves maintained in outdoor hutches. J. Anim. Feed Sci. 17: 139-146. 
Coleman, D.A., Moss, B.R. \& McCaskey, T.A. 1996. Supplemental shade for dairy calves reared in commercial calf hutches in a Southern climate. J. Dairy Sci. 79: 2038-2043.

Gonzalez-Jimenez, E. \& Blaxter, K.L. 1962. The metabolism and thermal regulation of calves in the first month of life. Br. J. Nutr. 16: 199-212.

Hepola, H., Hänninen, L., Pursiainen, P., Tuure, V.-M., Syrjälä-Qvist, L., Pyykkönen, M. \& Saloniemi, H. 2006. Feed intake and oral behaviour of dairy calves housed individually or in groups in warm or cold buildings. Livest. Sci. 105: 94-104.

Huuskonen, A., Khalili, H., Kiljala, J., Joki-Tokola, E. \& Nousiainen, J. 2005. Effects of vegetable fats versus lard in milk replacers on feed intake, digestibility, and growth in Finnish Ayrshire bull calves. J. Dairy Sci. 88: 3575-3581.

Huuskonen, A., Tuomisto, L., Joki-Tokola, E. \& Kauppinen, R. 2009. Animal performance and carcass characteristics of growing Hereford bulls under insulated, uninsulated and outdoor housing conditions in Northern Finland. Agric. Food Sci. 18: 16-26.

Jorgenson, L.J., Jorgensen, N.A., Schingoethe, D.J. \& Owens, M.J. 1970. Indoor versus outdoor calf rearing at three weaning ages. J. Dairy Sci. 53: 813-816.

Kauppinen, R., Kukkonen, S., Niemelä, P., Rissanen, A. \& Vaarala, S. 2002. Kasvatuslämpötilan vaikutus pikkuvasikoiden kasvuun ja rehunsyöntiin. Teoksessa: Marketta Rinne (toim.) Maataloustieteen Päivät 2002, Kotieläintiede, 9.-10.1.2002. Helsinki: Yliopistopaino. s. 164-167.

McKnight, D.R. 1978. Performance of newborn dairy calves in hutch housing. Can. J. Anim. Sci. 58: 517-520. MTT 2006. Rehutaulukot ja ruokintasuositukset. Maa- ja elintarviketalouden tutkimuskeskus, Jokioinen. Julkaistu 14.2.2006, [viitattu 26.11.2009]. Saatavissa internetistä: http://www.agronet.fi/rehutaulukot/.

Spain, J.N. \& Spiers, D.E. 1996. Effects of supplemental shade on thermoregulatory response of calves to heat challenge in a hutch environment. J. Dairy Sci. 79: 639-646.

Tuomisto, L., Huuskonen, A., Ahola, L. \& Kauppinen, R. 2009. Different housing systems for growing dairy bulls in Northern Finland - effects on performance, behaviour and immune status. Acta Agric. Scand., Sect. A, Anim. Sci. 59: 35-47.

Van der Fels-Klerx, H. J., Horst, H. S. \& Dijkhuizen, A. A. 2000. Risk factors for bovine respiratory disease in dairy youngstock in The Netherlands: the perception of experts. Livest. Prod. Sci. 66: 35-46.

Webster, A.J.F. 1971. Prediction of heat losses from cattle exposed to cold outdoor environments. J. Appl. Physiol. 30: 684-690. 